\title{
Growth of Government Urban- Village Development In Indonesia
}

\author{
Rahyunir Rauf \\ Lecturer of Governmental Science FISIPOL - UIR \\ Pekanbaru, Indonesia
}

\begin{abstract}
One of the government units in the governance system in Indonesia is the Village Government. Urban Village is one of the government entities in Indonesia. In the development of the village government experienced changes in line with the change of law on local government in Indonesia. The focus of this paper only discusses and analyzes the existence of the municipal government from 4 (four) laws on local government and the latest law on village governance, namely Law Number 5 Year 1979 on Villages separated by Number 5 of 1974 on Principal Public Government in the Region, Law Number 22 Year 1999 on Regional Government, Law Number 32 Year 2004 regarding Regional Government and the latest Law Number 23 Year 2014 on Regional Government, In Law Number 5 Year 1979 puts Urban village as a region and is the lowest government directly under subdistrict head. In Law Number 22 Year 1999 place the urban village as the work area of urban village head as a regional apparatus under subdistrict head. In Law Number 32 Year 2004 place the urban village as a Regional Device. Whereas in Law Number 23 Year 2014 place the urban village as a subdistrict device, so the consequence urban village head is no longer responsible to the Regent / Mayor but will be directly responsible to the District Head. This research uses literature study method. So it can be concluded that there are substantial changes in urban village government institutions in line with the change of Law on Regional Government and Law on Village Government in Indonesia.
\end{abstract}

Keywords: Urban Village, urban village Government, Administrative Region, District, Local Government.

\section{INTRODUCTION}

In the system of local government in Indonesia there is the government of urban village, the village headed by a urban village head. The position of urban village government is constantly changing as regulation changes. The focus of this paper is on the existence of the government of the urban village of the 4 most recent local and village laws, namely Law Number 5 Year 1979, Law Number 22 Year 1999, Law Number 32 Year 2004 and Law Number 23 Year 2014 on Regional Government. Law No. 5 of 1979 places urban village as a working area and is the lowest government directly under the subdistrict head. Law Number 22 Year 1999 places the urban village as the work area of the Village Head as a regional apparatus under the subdistrict head. Law Number 32 Year 2004 places the kelurahan as a Regional Device. Law No. 23 of 2014 places the urban village as a urban village apparatus,Law Number 22 Year 1999 places the urban village as the work area of the Village Head as a regional apparatus under the subdistrict head. Law Number 32 Year 2004 places the urban village as a Regional Device. Law No. 23 of 2014 places the urban village as a urban village apparatus.

\section{PROBLEM FORMULATION}

Along with changing the status of the urban village from one law to the law on other regional government, resulted in the change of government of the urban village from the position of the urban village, the relationship of the head of urban village with the head of sub-district, the responsibility of the village head and so forth. Therefore this problem is: "how is the development of urban village government in Indonesia?.

\section{DISCUSSION}

In essence, the basic function of the government is the service, both to provide government services, development services and community services, as stated by Sri Maulidiah (2014; 3)[1], that;"In essence the government is held to meet the basic needs of the community, namely the need for security, basically the country serves as night watchman, where most of the community keep most other people at night, so that the community fulfilled the need for security, order and peace. The basic function of government is "service", good government service, development, and social service and also empowerment.

Furthermore, the Government according to Sumaryadi $(2010 ; 18)[2]$, that;

"In general the government can be defined as an organization that has the power to create and apply laws and laws in certain areas. Government is an organization that has;

a. The governing authority of a political unit.

b. The power that governs a political society (political will) 
c. Apparatus is a functioning government agency to exercise power.

d. The power to enact legislation to handle disputes and administrative decisions with a monopoly over legitimate power.

Understanding the Government in the view of Ndraha (1997: 6-7)[3], namely;

"The government of social phenomena, occurs in relationships among community members, individuals with individuals, groups with groups, between individuals and groups. In English, the Government is called government (Latin Gubernare, Greek kybernan, meaning to steer, drive or control), so that the government's symbol is shaped steering ship ".

Furthermore, according to Ryaas Rasyd in Giroth (2004: 65) is;

"What the government, then the government interpreted as a fair process based on law to every citizen, providing services for the progress of the nation together. Furthermore, the main task of the government can be summarized into three main essentials, namely;

\section{a. Service \\ b. Empowerment \\ c. Development}

Further stated Sadu wasistiono $(2004 ; 41)$ [4], that; one of the most important tasks of the government is to provide public services to the public. Therefore, government organizations are often referred to as public servants. One of the local government units in Indonesia is urban village, the development of sub-district government in 4 laws is as follows:

\section{A. Village Government based on Law Number 5 Year 1979}

Based on Article 1 point (b) of Law Number 5 Year 1979 regarding Village, stated that; "An area occupied by a number of residents who have the lowest governmental organizations directly under the sub-district head, who are not entitled to hold their own household".

Based on Article 24 of Law Number 5 Year 1979, it is stated that;

1. Head of urban village is the main organizer and responsible person in the field of government, development and society in the framework of the implementation of local government affairs, general government affairs including the establishment of tranquility and order.

2. Head of the urban village is a Civil Servant appointed by the Regent / Mayor of the Head of the Second Level Region / Mayor on behalf of the Provincial Governor.Article 27 of Law Number 5 Year 1979 states that; In carrying out the duties and authority of the leadership of the village administration responsible to the official who has the authority to lift it.

Based on the foregoing articles, it can be stated that;

- Urban village is a region

- $\quad$ urban village head is appointed by the Regent / Mayor / Mayor

- $\quad$ urban village head is responsible to the Regent / Mayor / Mayor

- Working Relations with sub-district head is not explained

\section{B. Village Government based on Law Number 22 Year 1999}

Urban village under article 1 letter (n) of Law Number 22 Year 1999 is; the urban village head working area as a regency and municipal area.

Based on Article 67 of Law Number 22 Year 1999, it is stated that;

1. Urban village is a sub-district device headed by the village head.

2. Head of urban village is called urban village head

3. Village heads are appointed from eligible civil servants by the Regent/ Mayor.

4. The village head receives a partial delegation of government authority from the sub-district head.

5. The urban village head is responsible to the sub-district head.

Based on the above article, it can be stated that;

- urban village is the work area of urban village head

- urban village is a sub-district device

- urban village head is appointed by the Regent / Mayor

- The village head receives the delegation under the authority of the sub-district head

- urban village head is responsible to the sub-district head

- The relationship with the sub-district head is superior and subordinate

C. Village Government based on Law Number 32 Year 2004

Based on Article 127 of Law Number 32 Year 2004 stated that;

1. Sub-districts were formed in the sub-districts with local regulationand were guided by government regulations.

2. Village headed by urban village head who in the execution of his duties to obtain devolution from the Regent / Mayor.

3. The Village Head is appointed by the Regent / Mayor on the proposal of the Camat from civil servants who master the technical knowledge of the government.

4. In carrying out its duties assisted by the urban village.

Based on the above article, it can be stated that;

- Urban village is a regional device 
- urban village head is appointed by the Regent / Mayor

- urban village head receives delegation within the authority of the Regent / Mayor

- urban village head is responsible to the Regent

- Relations with the sub-district Head are coordinated.

D. Village Government based on Law Number 23 Year 2014

In relation to the position of urban village based on

Law Number 23 of 2014 According to Rahyunir Rauf (2016; 145)[5], that;

"Associated with the elements of regional devices can be stated:

1. In Law Number 23 Year 2014 stated that the element of the provincial area consists of five elements, consisting of the regional secretariat, the secretariat of the DPRD, the Inspectorate, the Regional Office, and the Regional Body. In Law Number 32 Year 2004 the provincial area consists of 4 elements, namely; The Regional Secretariat, the Secretariat of the Regional People's Legislative Assembly, the Regional Office and the Regional Technical Institute. In Law Number 23 Year 2014 consists of 6 elements, namely the regional secretariat, the secretariat of the DPRD, the Inspectorate, the Regional Office, the Regional Body and the District.

2. In Law Number 23 Year 2014, Urban village is not included in regency / municipal area, but urban village is a sub-district device.

Based on Law No. 23 of 2014, it is known that the former urban village is a regional device, while it is now a urban village device. Urban village according to Article 229 paragraph (2) of Law Number 23 Year 2014 is; "urban village is headed by a Village Head called urban village head as a sub-district device and is responsible to the sub-district head.

Urban village is a sub-district device, urban village is formed by Regency / City Regulation. Urban village head appointed Regent / Mayor on the origin of the regional secretary of the eligible civil service area. Based on the above description, it can be stated;

- urban village is a sub-district device

- urban village head is appointed by the Regent / Mayor

- urban village head receives delegation within the authority of the Regent / Mayor

- Urban village head is responsible to the Regent

- The relationship with the urban village head is superior and subordinate (hierarchical)

\section{CONCLUSION}

Based on the description and analysis in the previous section, we can draw some conclusions that are abstracted in the form of the table below:
Table. 1. Comparison the Law about Local Government

\begin{tabular}{|c|c|c|c|c|c|}
\hline $\begin{array}{l}\mathrm{N} \\
\mathrm{O} \\
\end{array}$ & Indikator & $\begin{array}{l}\mathrm{UU} \\
5 / 79\end{array}$ & UU 22/99 & $\begin{array}{c}\mathrm{UU} \\
32 / 04\end{array}$ & UU 23/14 \\
\hline 1. & $\begin{array}{l}\text { Institutio } \\
\text { nal }\end{array}$ & Area & $\begin{array}{l}\text { Working } \\
\text { area }\end{array}$ & $\begin{array}{l}\text { Not } \\
\text { explained }\end{array}$ & $\begin{array}{l}\text { Not } \\
\text { explained }\end{array}$ \\
\hline 2. & Position & $\begin{array}{l}\text { Not } \\
\text { explai } \\
\text { ned }\end{array}$ & $\begin{array}{l}\text { Sub- } \\
\text { district } \\
\text { device }\end{array}$ & $\begin{array}{l}\text { Regional } \\
\text { Devices }\end{array}$ & $\begin{array}{l}\text { Sub- } \\
\text { district } \\
\text { device }\end{array}$ \\
\hline 3 & $\begin{array}{l}\text { Appoint } \\
\text { ment }\end{array}$ & $\begin{array}{l}\text { Regent } \\
\text { / } \\
\text { Mayor } \\
\text { madya } \\
\text { / } \\
\text { mayor }\end{array}$ & $\begin{array}{l}\text { Regent / } \\
\text { Mayor }\end{array}$ & $\begin{array}{l}\text { Regent / } \\
\text { Mayor }\end{array}$ & $\begin{array}{l}\text { Regent / } \\
\text { Mayor }\end{array}$ \\
\hline 4 & $\begin{array}{l}\text { Account } \\
\text { Answer }\end{array}$ & To & Camat & $\begin{array}{l}\text { Regent / } \\
\text { Mayor }\end{array}$ & Camat \\
\hline 5 & $\begin{array}{l}\text { Source } \\
\text { Authority }\end{array}$ & & $\begin{array}{l}\text { Delegatio } \\
\mathrm{n} \text { of } \\
\text { authority } \\
\text { of Sub- } \\
\text { district }\end{array}$ & $\begin{array}{l}\text { Regent / } \\
\text { Mayor }\end{array}$ & $\begin{array}{l}\text { Regent / } \\
\text { Mayor }\end{array}$ \\
\hline 6 & $\begin{array}{l}\text { Work } \\
\text { relations } \\
\text { hip } \\
\text { with the } \\
\text { Sub- } \\
\text { district } \\
\text { Head }\end{array}$ & $\begin{array}{l}\text { Not } \\
\text { explai } \\
\text { ned }\end{array}$ & $\begin{array}{l}\text { Tops / } \\
\text { Subordin } \\
\text { ate } \\
\text { (hierarchi } \\
\text { cal) }\end{array}$ & $\begin{array}{l}\text { Coordina } \\
\text { tion }\end{array}$ & $\begin{array}{l}\text { Tops / } \\
\text { Subordin } \\
\text { ate } \\
\text { (hierarchi } \\
\text { cal) }\end{array}$ \\
\hline
\end{tabular}

\section{REFERENCES}

[1] Maulidiah,Sri. Pelayanan Publik; Pelayanan Administrasi Terpadu Kecamatan(PATEN), Indra Prahasta, Bandung.2014.

[2] Nyoman, Sumaryadi, Sosiologi Pemerintahan; Dari Perspektif Pelayanan,Pemberdayaan, Interaksi, dan Sistem Kepemimpinan Pemerintahandi Indonesia, Ghalia Indonesia, Jakarta,2010.

[3] Taliziduhu, Ndraha, Ilmu Pemerintahan (Kybernologi), Rineka Cipta,Jakarta.1997.

[4] Sadu, Wasistiono dan Fernandes Somangunsong, Metodologi Ilmu Pemerintahan(Edisi Revisi Yang Diperluas), IPDN Press, Sumedang/Bandung. 2015

[5] Rahyunir, Rauf, Posisi Dewan Perwakilan Rakyat Daerah Dalam Sistem PemerintahanDaerah, Marpoyan Tujuh, Pekanbaru.2016.

[6] Rahyunir, Rauf,Panduan Umum Evaluasi Kinerja Kecamatan, Marpoyan Tujuh,Pekanbaru,2016.

[7] Lexy, M.Giroth, 2004, Edukasi dan Profesi Pamong Praja, Public Polecy Studies, Good Governance and Performance Driven Pamong Praja, STPDN Press, Jatinangor. 